Portland State University

PDXScholar

Anthropology Faculty Publications and

Presentations

Anthropology

$12-1995$

\title{
Sri Lanka's "Army of Housemaids": Control of Remittances and Gender Transformations
}

Michele Ruth Gamburd

Portland State University, b5mg@pdx.edu

Follow this and additional works at: https://pdxscholar.library.pdx.edu/anth_fac

Part of the Social and Cultural Anthropology Commons

Let us know how access to this document benefits you.

\section{Citation Details}

Gamburd, Michele Ruth, "Sri Lanka's "Army of Housemaids": Control of Remittances and Gender Transformations" (1995). Anthropology Faculty Publications and Presentations. 45.

https://pdxscholar.library.pdx.edu/anth_fac/45

This Post-Print is brought to you for free and open access. It has been accepted for inclusion in Anthropology Faculty Publications and Presentations by an authorized administrator of PDXScholar. Please contact us if we can make this document more accessible: pdxscholar@pdx.edu. 


\title{
SRI LANKA'S 'ARMY OF HOUSEMAIDS': CONTROL OF REMITTANCES AND GENDER TRANSFORMATIONS
}

1 December 1995

\author{
Michele Ruth Gamburd \\ Department of Anthropology \\ Portland State University \\ P. O. Box 751 \\ Portland, OR 97207-0751
}

\begin{abstract}
:
When the mass labor migration of women to the Middle East began in the early 1980 's, many Sri Lankan social scientists predicted a revolution in gender equality and a greater participaton by women in political and economic decision-making as a result of employment abroad. Noting that gender rarely correlates in predictable ways with social change, and questioning the dominant teleological ideology that change always happens for the better, this paper looks at relations between female migrants in a coastal village in the Southwest and the people responsible for spending and saving the money they remit to the village. Several case studies reveal the extent to which men have not taken over tasks such as child care and household chores. In allmale drinking groups, unemployed husbands reassert their masculinity in the face of their wives' new role as breadwinner. The values of the drinking community stand in implicit opposition to values channeling family resources towards 'getting developed' (diyunu venavaa), the dominant village idiom of successful migration. Several women's stories document their struggles, including the ultimate protest of a suicide attempt, to control the money they sent back to the village. In cases where women's work has bettered their family's economic standing in the village, women and their husbands and fathers enjoy new social privileges and authority. Finally, migration as an avenue of escape provides a new option for women caught in untenable home situations. By examining the gendered power dynamics of the microprocesses of social change, this paper explores the extent to which women's lives have and have not improved through migration.
\end{abstract}

\section{INTRODUCTION}

This paper examines gender hierarchies and status relations in a Sri Lankan village as affected by the large and growing migration of female labor to the Middle East. The burgeoning of female labor 
migration in the mid-1980's brought women's labor into the national limelight. $75 \%$ of the estimated 500,000 Sri Lankans working abroad in 1992 were female, with most working as housemaids in Saudi Arabia, Kuwait, the United Arab Emirates (U.A.E.), and other oilproducing states in the $\mathrm{Gulf}_{2}$. Sold for wages on the global market, the services housemaids usually performed at home for free suddenly acquired monetary worth, blurring the line between the domestic and the public. A commodity on the global market, rendered for strangers, regulated by national and international laws, women's work leapt to the national consciousness. The Sri Lankan government supported the massive migration of labor, which not only reduced the intensity of the unemployment problem by drawing off surplus labor, but also provided the country with a source of valuable foreign exchange. Domestic workers formerly missed in all employment surveys became 'our army of housemaids'.

Home to roughly a hundred fifty families and a thousand people, the village I call Kosgahakanda ${ }_{3}$ lies on the lush tropical southwest coast of Sri Lanka. While three decades ago cinnamon production and coconut fiber industry employed most of the villagers, the past fifteen years have seen dramatic shifts in the local economy. Jobs in the armed forces, in the tourist industry, and in local garment factories now employ significant numbers of local men and women, but the migration to the Middle East overshadows all other forms of work. In 1994 I found that over a quarter of the village households ${ }_{4}$ held current or returned migrants. With women making up $90 \%$ of the local and $75 \%$ of the national migrant populations, this change in economic orientation augurs transformations in village and national gender hierarchies, with a large range of local tensions and conflicts arising as women step into the role of wage-earner. 


\section{NEGOTIATING IDENTITIES}

\section{'Getting Developed'}

By the most frequently voiced village standards, the goal of migration is 'diyunu venna' ${ }_{5}$, 'to prosper or improve', or 'to get developed'. A person, family, village or country can 'diyunu venná', or acquire more wealthy, knowledge, or assets. Saying 'minissu vaeDi diyunu venavaa' means that people have become rich and prosperous, or 'diyunu vecca minissu'. 'diyunu raTaval' are 'developed countries'.

Visible display of wealth counted as 'getting developed'. Almost unanimously, women and men said that migrants went abroad because they wanted to buy land and build a house. In 1968, only families from the highest caste ${ }_{6}$ in the village lived in cement or brick houses with tile roofs, while the poorer families lived in clay houses with tin sheets, tar sheets, or coconut frond mats as roofing. Since 1968 population pressure and fragmentation due to inheritance practices had reduced the size of individual home gardens, though the wealthiest villagers still retained the largest land shares. More dramatically, villagers had applied the influx of money from the Middle East to improve their housing. Whereas a cement house with a large garden once unequivocally indicated a wealthy residence, in 1994 in the village area large, people of all grades and castes owned cement houses (often only half finished) on relatively small plots of land. All who could built good quality houses, for comfort, health, and prestige. A cement house chronicled the high water mark of money, regardless of continued affluence in the household. Although the diacritic of a good house also indicated wealth in 1969, in 1994 the speed with which family affluence could change had greatly increased. In 1969 the rise and fall of fortune roughly paralleled the 
life cycle of the house; rich families had big cement houses, and poor families had small clay ones. In 1994, some families went hungry in half finished mansions, while others stored color televisions under palm-frond roofs. Access to money through migration gave more people the means to improve their standing through land and housing, thus throwing the scale itself into flux as an indicator of relative wealth and caste status.

Although some migrants permanently improved their social standing, oftentimes families channeled a migrant's earnings to family consumption. Family consumption did not count as a waste in most villagers' opinions, and even families who 'got developed' admitted to dipping occasionally into savings. Assuming the husband would continue to work, the family counted on his salary to support most if not all of the immediate local needs. Where husbands did not work, however, often little or nothing remained of the migrant's wages but what she might have saved with her in the Middle East or invested in jewelry. Jobs available for unskilled male workers in the village were sporadic, labor intensive, difficult, not highly paid, and undesirable. Often men preferred not actively to seek out such opportunities, especially if their wives earned good salaries abroad. Local, national and international observers shared a critical attitude towards such instances of voluntary un(der)employment, especially when the family 'failed to develop' 7 . With the common trope, 'He sits idly, drinks, and wastes' ${ }_{8}$, many women expressed frustration with idle husbands. Although they held repaying loans and sustaining a family without further debt as laudable objectives, they did not view these accomplishments as 'improvement' per se.

An Interview with Rukmini

Much of my research consisted of interviews with people 
who had worked in the Middle East, and with family members of migrants at that time abroad. I usually conducted interviews in Sinhala, in the homes of the families I spoke with. One of my two research assistants, Mr. Siri de Zoysa and Mrs. Sita Mendis, usually accompanied me for interviews. Long-time local residents, Siri and Sita provided invaluable insights into village history, current rumor, kinship connections, political alliances, and other relevant interpersonal dynamics. The three of us often attended ceremonies, rituals and celebrations, as well as circulating more informally through the village.

The following case study represents a typical if slightly extreme example of voluntary male unemployment and the concomitant use of a migrant woman's wages for family consumption. Husband and wife struggled to explain to me and to themselves their lack of 'development' despite seven years of work abroad, in the process negotiating the meaning of their poverty and its affect on individual and family identity.

Siri and I interviewed Hema, an elderly Berava (Drummer) caste woman, and her son Ramesh, asking about Ramesh's wife Rukmini, who was then abroad working as a housemaid. Rukmini, about thirty years old, had spent most of the past seven years abroad. During the four years Rukmini worked in Jordan, she sent her money to her own mother. Having no stable home, Rukmini's mother went from child to child, staying roughly six weeks with each, spending lavishly from the checks Rukmini sent, under the pretext of looking after Rukmini's daughter. The next time Rukmini went abroad, she left her daughter with her mother-in-law Hema instead. While Siri, Hema, Ramesh and I sat in the shade of Hema's unfinished cement house, Siri explained to me that Rukmini did not send money to her husband Ramesh, an infamous drinker and gambler. The ice broken 
by Siri's accurate but joking assessment of the situation, Ramesh's mother Hema took over the story, saying that she had told Rukmini not to send money, but to keep it herself. Feeling Ramesh's racebetting and drinking left no balance money even to support himself and his daughter, Hema said Ramesh had taken credit with many local stores and owed interest-bearing debts to several moneylenders. Sober and embarrassed, Ramesh, who used to drum and do labor work, did not deny that he had done little to support himself since his wife went abroad. Hema suggested that if Ramesh could earn money for himself and his daughter, his wife could save all of her salary, and they could buy land and build a house, the original goals of her migration. I asked Ramesh about his work. He said he made about Rs. 125/ (US\$ 2.50, a good salary) a day, plus food when he drummed; he also worked occasionally as a laborer. Taking us into the small two room clay house where he, his mother, father, daughter, and several brothers all lived, Ramesh showed us a crowded collection of furniture (table, chairs, bed, and cabinet with broken glass) bought with Rukmini's savings from her work in Jordan. Upon her return to the village for the New Year holiday in mid-April 1994, I asked Rukmini to come to my house to talk about migration to the Middle East. Usually I spoke with people at their own houses, but at the time of the interview, Rukmini and Ramesh were living in a tiny six foot by twelve foot tiled lean-to built against the new cement wall of Hema's unfinished house. Unexpectedly, Ramesh came along to the interview. Drunk for the New Year holiday, Ramesh wanted to talk to us, or at least to hear what Rukmini had to say to us, and to correct her where he felt it necessary. Although being drunk at 2:00 in the afternoon was not exceptional for men in the village, especially around the New Year holiday, people rarely if ever came drunk to an interview with me. 
Under ordinary circumstances, I would probably have done a brief interview with both Rukmini and Ramesh, and then tried later to interview Rukmini alone. Since I was leaving for the United States in only two days, and since Rukmini had just returned home, both of our schedules were busy and this represented our only opportunity to talk. With Ramesh on the porch, Sita and I found that Rukmini could barely finish a sentence without him breaking in with commentary. Quickly sizing up the situation, Siri, who had planned to work on kinship charts in the other room during the afternoon, came to the rescue, politely and repeatedly coaxing Ramesh off the porch so that Sita and I could talk with Rukmini.

Palpable tension between Rukmini and Ramesh pervaded the interview. When I asked Rukmini about the gifts she had brought back from the Middle East, Ramesh, who had rejoined us on the porch despite Siri's efforts, said that Rukmini had given him a shirt, but he had gotten his sarong for himself. She replied that she had given him a shirt, shoes, and cigarettes. She left her comment at that; it was only later that Siri, who had gotten the full story from Ramesh, explained the implicit barb. Rukmini had given Ramesh a new pair of sandals, a pack of prestigious foreign cigarettes, and a new shirt. The police had raided the illegal toddy (coconut beer) brewery where Ramesh had gone to drink, and he had run through a drainage canal to the ocean. Ramesh escaped arrest, but the canal muck claimed his brand new sandals, and the salt water ruined the pack of cigarettes in his shirt pocket. Siri said that Rukmini had also brought back twelve beers and two whiskey bottles, all already consumed. Ramesh replied to Rukmini (in what seemed to us at the time a non sequitur) that even if he drank, he still saved her clothing. Sita, Siri and I later decided he must have been comparing himself favorably with another husband of a Middle East migrant, who had sold his wife's dresses 
during her absence. Siri then persuaded Ramesh to go and inspect a rare plant in the garden.

With Ramesh gone, I asked Rukmini if she planned to go back to the Middle East. Saying she intended to go back 'no matter how', Rukmini explained animatedly that she had gotten "fed up" with her husband's drinking. Speaking very quickly, she lamented that there was no use earning money when he was drinking. Although she liked to come home and see her daughter, problems with her husband 'unsettled her mind'. Complaining that her husband never listened to her, Rukmini said, "He breaks things and wastes and drinks" 9 . Rukmini's variation on the common trope, "He sits idly, drinks, and wastes" ${ }_{10}$, showed she felt Ramesh's destructive behavior to be worse than the indolence and dissipation sedimented in the rhetorical phrase.

Ramesh returned to the porch. Hoping for a neutral topic, perhaps a story of childhood illness, I asked Rukmini what had been the worst time in her life. She said the hardest part of her life started after getting married. Ramesh exclaimed, 'Really?' They talked heatedly about a fight several years earlier that had ended with both of them filing separate complaints at the police station at the junction, a common conclusion to serious village disputes. Protesting loudly, Ramesh drunkenly accused his wife of abandoning their daughter and neglecting her duties. Silenced, Rukmini picked up Sita's umbrella from the table, examining it with great care. Center stage and unchecked, Ramesh went on talking about himself and how hard he had been working for the family's sake. Ramesh's monologue continued for several minutes, without Rukmini's interaction, Sita's translation assistance, or my note-taking. In the uncomfortably confrontational atmosphere, Rukmini slouching low in her the cane 
armchair, turned slightly away from her husband. I caught her eye and winked at her. Suddenly sitting up straighter and relaxing physically, Rukmini told Ramesh to go home and she would answer my questions.

Not well versed in the cross-cultural connotations of winking, this was my only use of the wink as interview technique. As I read the situation, Rukmini had worried I would accept at face value everything I heard about how she had neglected her family and how hard Ramesh had worked to make up her shortfall; my wink positioned me with many local women, who listen to men without interrupting or contradicting, but also without believing all that they hear. Realizing Ramesh's impaired state but recognizing his cultural prerogative as a male to dominate the conversation, none of the women on the porch that afternoon challenged his assertions beyond Rukmini's initial spirited protest that her married life had been hard. Rukmini, caught between the wish to defend herself and the embarrassment of arguing with a drunken husband in front of a foreigner and two higher caste villagers, chose silence as her best defense until my unvoiced support assured her that none of us took Ramesh's drunken ramblings seriously. That leverage allowed her not to confront his misrepresentations directly, but to ask him to leave. In other situations where sober men dominated conversations, I often found women approached me later in private with contradicting information they had not wanted to voice in public. While for the most part accepting men's right to dominate the public transcript (Scott 1990), women made ample use of other opportunities to make their own opinions heard.

That afternoon on the porch Rukmini and Ramesh negotiated interpretations of their continued poverty and their failure in the community mind to 'get developed'. Each attempted to control the 
narrative, influence judgments and shape appraisals. I look at the husband-wife dynamics in this interview as a struggle over meaning in the making, as each attempted to define his or her own agency, identity, and self-worth with respect to the story. By including himself in my invitation to talk, and by excluding Rukmini from conversation when he could, Ramesh sought to prevent Rukmini (and me) from portraying Rukmini as the decision-maker and breadwinner. Ramesh wanted to be thought of as part of a team, even as leader, instead of as a dead weight, or someone who 'sits at home idle, eating while his wife works'. His monologues sought to retell the story of what happened to all the money Rukmini had sent home, simultaneously reworking his own image in his and my eyes.

Despite spending seven years abroad, Rukmini had not accumulated significant savings. When I asked during the interview what Rukmini envisioned her life to be like in another ten years, she said that she would like her whole family to live in a nice house of their own. Although she had already saved enough money for some land, she could not yet afford to put up a house, and planned to return to the Middle East to work again ${ }_{11}$. After Ramesh and Rukmini left our porch, Siri, Sita and I discussed their situation. Voicing a unanimous village assessment, Siri commented, "It's a real shame / sin, that she/ they are living (like that) having just come from the Middle East." ${ }_{12}$ Siri and Sita speculated whether the family had enough good food to eat. Seeing Rukmini as pressured from all sides for money, Sita portrayed not only Ramesh, but many members of Rukmini's extended family as negotiating their relationships with her, which they judged by the sort of present she gave them. Despite Rukmini's generosity, many were disappointed. Sita doubted if enough money remained even for a small piece of land as Rukmini 
had asserted. Although housemaids cannot directly supervise the handling of the money they remit, they have the right to keep some or all of their earnings with them abroad. The distribution of money for consumption must have taken place with Rukmini's explicit, or at least tacit, consent. Nevertheless, Rukmini also held the goal of buying land and building a house, and felt some disappointment for having very little of lasting material worth to show for her six years abroad. Rukmini walked a difficult line between giving and saving, between preserving and strengthening family ties by redistributing money, and 'getting developed'.

Alcohol: Group Bonding and Masculinity

Much of the money Rukmini brought home went to settle Ramesh's debts and to finance his New Year drinking binge. Drinking, a mark of wealth (if only temporary in certain cases) and masculinity, preoccupied many of the under- and unemployed village men. Men and women talking about families that did not 'get developed' from female migration to the Middle East often put the blame on husbands like Ramesh, who quit work and took to drinking in the absence of their wives. At once scorning and tolerating such husbands, villagers included drink in the common trope, 'He sits idly, drinks, and wastes'. When I inquired into the motives for their behavior, several people suggested that the drinking men emulated richer land owners of the previous generation. One village notable explained to me, 'It is good to be rich and look idle; in the absence of riches, looking idle will suffice.' Hard work, particularly physical labor, carries significant stigma in the village; light skin, clean white clothing, and a sweatless brow indicate leisure, high status, or at the very least a respectable office job out of the burning sun.

Alcohol was a rich and multivocal point of reference in the 
village; it was a business, a medicine, a pleasure, a need, and a mark of masculinity. It was the despair of many a wife, and a basis of community between drinking buddies. Part and parcel of the phenomenon of the idle husband came the role of alcohol in village society. When Rukmini came home, Ramesh made claims on her money, mainly using it to drink and improve his status as buyer of 'rounds' and patron of poorer male friends and relatives who also wished to drink. Recognizing his needs, upon her return Rukmini provided him not only with money but also with high-prestige foreign liquor.

Complicit in her husband's addiction, Rukmini nevertheless sought to set limits on his drinking. While men felt shame for living off money their wives send from abroad, blame often fell on the absent woman, without whose control a man drifted helplessly into bad habits and bad company. Women bore the responsibility of disciplining the family and regulating household finances; village discourse held the wife largely responsible for any misadventures that might befall her husband during her stay abroad. Constitutionally incapable of controlling his own behavior, the man depended on his wife to regulate his conduct, despite the fact she held little authority with which to enforce her responsibility.

Usually a male social activity, alcohol drinking in the village did not correspond to what many Westerners would call 'social drinking', or having a beer or a few cocktails before dinner. Villagers distinguished between men who drank occasionally at celebrations, funerals, and with friends on the one hand, and those who drank regularly with a group dedicated to that purpose. At weddings, funerals, and other mixed-sex social get-togethers the host would often 'run a bottle' of hard liquor out of a back room visited surreptitiously by most of the male guests, who became progressively 
drunker as the event proceeded. Even in the cases villagers deemed acceptable drinking, men condemned eating while drinking because it reduced the 'current' or high ${ }_{13}$. Where men strove to get as drunk as possible as quickly as possible, 'drinking to excess' was the norm, not the exception to the rule.

Extremely expensive in the village, a bottle of the local hard liquor, arrack, cost roughly what a manual laborer might earn in a day. For almost every family in the village, if a man drank as much as socially required, he would have spent a more than his family could afford. Women, who rarely if ever touched alcohol, applied a constant gendered pressure to spend money for family consumption instead of for alcohol. Villagers often blamed a man's drinking on his wife's absence, many people also noted that characteristic patterns of drinking and spending, as well as failure to 'get developed', predated, and often prompted, female migration . $_{14}$ To save money, most local men drank 'kasippu', the local moonshine ${ }_{15}$ engaging in recurrent games of hide and seek with the police, as well as with their wives.

The consumption and production of alcohol formed a large sub-section of the village economy. Despite debts and hunger in the family, some men spent a great deal on alcohol. Kasippu manufacturers, who distilled at night, in remote, wooded places, employed large numbers of local men. Offering wages of Rs. 150/ (US\$ 3) a night, with free food and drink, one village outfit went into production twice a week, running three stills all night, with each still requiring six people's constant attention. Including production crews, complicit landowners and law enforcement officers, and distribution networks, the business (one of several in the area) directly involved over fifty individuals. Among the wealthiest people in the area, Kasippu king-pins paid their laborers well, but this money rarely 
resurfaced to build houses and buy land.

Drinking groups, often centered around a particular kasippu producer, formed strong factions of loyalty and identity within the village. Shifting groups of local men, usually of similar age and status, gathered together regularly to drink, surreptitiously visiting a distribution center several times, or purchasing a bottle and taking it to a private location. Often those with money sported drinks for those without, receiving the favor in return at a later date. Providing drinks free to others, and working with the manufacturer, ensured ready access to liquor in one's own less affluent times.

Although rarely acknowledged by the more respectable leaders in the village, drinking groups carried political power. Heavy drinkers adopted the values and norms of their group, which tolerated, even encouraged, such activities as gambling, stealing, rape, and assault. British anthropologist Jonathan Spencer glosses 'lajja' as shame, shyness, social restraint, all essential ingredients of good public behavior. He glosses 'lajja-baya' as shame-fear, particularly the fear of ridicule and public humiliation (1990: 169-172). Those who drink are thought not to know 'lajja' or 'baya', and "It is assumed that people who drink alcohol will no longer be in control of their actions and easily aroused to anger which would be likely to spill out in physical violence, given the opportunity"(1990: 183). Outsiders occasionally employ such people to assault opponents (within and outside the village) and burn their houses and property (Ratnapala 1985). Other villagers feared such drinking groups, especially those with histories of thuggery and intimidation.

At the same time, drinking men remained integrated into the structure of village kinship and friendship networks, and producers provided generous financial and other support and protection to individuals and to village institutions such as schools and temples. 
Kasippu production groups maintained guardedly friendly ties with individuals among the law enforcement officers, and often contributed financially to individuals with political power. For reasons spanning from loyalty to fear, villagers rarely challenged drinking groups, or reported their misdeeds to higher authorities (many already complicit in the network).

As a woman and a foreigner I never participated in any drinking group activities, and while I gathered a great deal of secondhand information about the 'who', I can only speculate on the 'why' of group involvement. An extenuating circumstance that could be acquired whenever needed (Ratnapala 1985:26, Fekjaer 1993), drunkenness provided the perfect alibi for deeds of poor judgment and socially unacceptable actions, allowing responsibility to fall outside, on the substance itself for any foolish actions, and on the absent controlling social structure, the wife, for the drinking itself. Alcohol consumption provided relief from personal responsibility for men who failed to earn as much as their wives or who failed to apply their wives' salaries towards 'getting developed'. With development in the village resting primarily on female migration to the Middle East, some men may have looked to their male peer group to reassert their self worth in the face of the loss of male power and respect inherent in their wives' new economic roles. Involvement with kasippu production and distribution provided poor men with alcohol, money, community, and a mode of rejecting the dominant idiom of 'getting developed'. Drinkers thus paradoxically emulated the idle rich of prior generations, while rejecting the work ethics of the newer breed of wealthy villager. Migration and alcohol consumption inextricably intertwined in the construction of new identities for village men and women. 
Joker, Simpleton, Free Thinker: Lal

Tagged as one of the most successful village families involved with the migration of labor to the Middle East, Indrani and her husband Chandradasa represent a new elite in the Kosgahakanda area. Chandradasa worked as a security officer at a hotel near Colombo, returning home for the weekend twice a month. Siri said that they had used their money "in a perfectly correct way", saving and spending both spouses' salaries wisely. In Indrani and Chandradasa's absence, Chandradasa's mother and brother took care of their five children and supervised the construction of their new house. Although Indrani named her mother-in-law as the primary care giver, the older woman's arthritis severely restricted her movements, and the children's uncle Lal did the lion's share of the cooking and housekeeping. Lal, a puzzling and unusual individual, forms the focus of the rest of this section.

Living across the road from Siri's house, Lal drew drinking water from the well in Siri's garden. Members of our household replied to the greetings Lal called out every time he entered the compound, with teasing comments and questions. About the state of the meal Lal was preparing, Siri invariably asked, 'Is the (cooking) course over?' ${ }_{16}$. For a man to study cooking in school would be just slightly more astounding than to find him cooking at all. In a world of simple structural reversals, when the houseworker leaves to earn a living, one might expect the former breadwinner to do the housework. On a village level, with a large number of women absent at any one time, one might expect unemployed and underemployed men to step in and help out with childcare, cooking, and other chores. In the cultural melieu of Kosgahakanda's extended families, however, not men but other women took over 'feminine' chores, with 
grandmothers and aunts looking after the children left at home. Lal, a man who cooked, kept house, did laundry and shopping, and took care of children, was a figure of some astonishment and amusement in the village.

Not very attractive by village standards, Lal had married at his mother's insistence some six or seven years before I met him. His beautiful wife first asked him to move to her relatives' home in the capital; when he refused, she found work in the Middle East, and never returned to the village. Although fairly sure that she had come home safely, Lal had no desire to visit her relatives in the city to see her again. When Indrani left for U.A.E., Lal and his mother moved in with Chandradasa to look after the children.

One afternoon in November, the nearly-illiterate Lal asked Siri's father (the local Justice of the Peace) to write a letter to the Graamaseevak $\underline{a}$ (Local Government Administrator) asking to be put on a list to receive a house from a local Non-Governmental Organization (NGO). The JP deliberately and in jest wrote a completely unsuitable letter telling the Graamaseeva $\underline{a} \underline{a}$ the stark truth, that Lal lived in a good cement house with electricity and a television. (Lal's official residence, a collapsing clay house, formed the basis of a subsequent successful application.) The innocent Lal took the letter to the Graamaseevak $\underline{a}$ who, upon reading it, said, 'This won't do at all,' and suggested that he and Lal both go talk to the JP. Once on the JP's porch, the JP and the Graamaseevak $\underline{a}$ took the opportunity good humoredly to corner Lal and ask him questions about his personal life.

Siri, curious but sensing himself not welcome in the discussion, took a long bath at the well adjacent to his father's porch, and overheard the gist of the conversation. The JP and the Graamaseeva $\underline{\text { a }}$ teasingly peppered Lal with questions about his wife, 
asking if he had sent cards and sweets to her in the Middle East. They also asked about Lal's private sexual life, determining that Lal did not know 'Which end was up,' which Siri thought might account for Lal's wife's desertion. ${ }_{17}$ Having exhausted the topic, the JP wrote a suitable letter for Lal. Siri was of the opinion that the Graamaseevak $\underline{a}$ and the JP had planned the whole scenario in advance.

When Siri and I interviewed Lal several days earlier ${ }_{18}$, he spoke about a series of manual jobs and positions as 'office peon' 19 . About forty years old at the time I knew him, Lal had not held an official job since he was hit by a van while walking on the side of the road in 1987. Lal said that he had no wish to return to work, and no ambitions to set up a business. Lal's mother, who had persuaded him to marry in the first place, thought he should do so again. Quoting a proverb, Lal said, 'The man who is hit with the fire brand from the fire, is afraid even of the fire-fly, ${ }_{20}$ (the local equivalent of 'Once bitten, twice shy,'). After his mother's death, when all of his family duties were fulfilled, Lal said he would like to become a monk.

Lal's usual calm, slow, joking style made him a hard target to tease. Of the recipients of government aid, he was the only man who waited in line with the women to collect food at the local Coop. Lal regaled those pointing out his feminine behavior with humorous stories of his finicky tastes in groceries; attempting to laugh at him, people found themselves instead laughing with him, about the dead gecko in the rice bag and the dried fish so smelly it must have been fertilizer. He met comments on his domesticity with exaggerated stories of the latest crises in the kitchen, the rough quality of a new soap, and the price of beans. Lal's complaints were uniformly within his 'feminine' role, not about it. He created an ambiguous self-image, 
somewhere between a simpleton with no understanding of his failure to fulfill a man's proper role, and a free-thinker impervious to criticism holding a singularly different set of values. With his baffling opacity and his non-stop wit, Lal carved out a unique space for himself as a male mother and housewife. The good-humored probing of the Graamaseev $\underline{a} \underline{a}$ and the JP indexed at once the community's awareness of Lal's unusual behavior, and their baffled and amused acceptance.

Lal's role of male mother complemented the new status and prestige his sister-in-law Indrani's accumulated wealth gave her in the village. Several days after her return from the Middle East, three village youths asked her to 'open' a free sago pudding community food distribution event ${ }_{21}$. Solicited in advance, Indrani's financial contribution was generous. Although Indrani said she had had no other such requests, she mentioned that she and Chandradasa had contributed to a large ceremony at the temple. 'Opening' occasions and making donations to the temple, formerly the domain of certain wealthy men from $\mathrm{HH}$ caste families, index Indrani's family's 'development', economic clout, and new access to power and authority. Their financial capital metamorphosed into the prestige of the symbolic capital (Bourdieu 1977) of respect and renown.

Within three or four days of their return from the Middle East, women often made offerings to the Buddhist temple and the Hindu shrine $_{22}$. These offerings expressed thanks for a safe and prosperous migration, while also promoting the spiritual development or 'merit' ${ }_{23}$ that came from making donations to the temple. Those who could made substantial contributions to annual religious ceremonies, while also contributing to secular festivals ${ }_{24}$. Watching cynically for signs of returning poverty, villagers recognized the 
difficulty of maintaining Middle East wealth without repeat

migration. Patrons sustaining their positions for a significant length of time achieved recognition in the village as someone who had truly 'gotten developed'. Along with buying land and building a house, contributing lavishly to community projects symbolized a rise in prestige and social standing, entitling one to positions of authority in community politics and temple decision-making, formerly the domain of wealthy, $\mathrm{HH}$ caste men. Although the most successful migrants from Kosgahakanda were $\mathrm{HH}$ caste men, a newly wealthy Berava caste family and several women from the HKK caste have made significant contributions to the village, indicating their potential bids to increased village status.

How Lal and Indrani would negotiate the transformation of their roles when Indrani returned permanently to the village remained to be seen. If Indrani resumed the household chores, would she still retain the status and prestige her migration gave her? Would Lal relinquish the care of his nieces and nephews and his somewhat comic role of male housewife? Towards the end of my stay in the village, funded by his brother and sister-in-law, Lal started a new cement house on his land, saying that he and his mother would move to that house when Indrani returned from the Middle East ${ }_{25}$. With a new cement house, Lal would also count as someone who 'got developed', and thus as someone of significance in the village.

Several common trends can be traced between the diametrically opposed cases of the community-diagnosed success of Indrani's family and the failure of Rukmini's to 'get developed'. Grete Brochmann (1987) noted that families that rely on migrants' remissions for daily consumption could rarely rise up out of poverty or amass the money to buy a house. Gunatilleke (1992) remarked 
that families with pre-existent resource bases had much greater chances of successful migration than those without. Budgeting abilities, clear priorities, and good communication within the family also facilitated successful migration. Without shared perceptions of benefits and responsibilities for all family members involved, potential for wasting money increased.

Rukmini's husband and mother distributed her remittances widely through family and drinking group networks; when Rukmini returned to Sri Lanka she found not savings but debts. In contrast, Chandradasa saved his wife's wages, supporting the family on his own generous salary. Already wealthier than average in the village, Chandradasa and his wife shared a common goal for her migration, and successfully implemented their plan, accumulating wealth while redistributing a portion of the profits to close family members such as Lal, and to community projects. Social prestige (such as Indrani's donation to the free sago house) also counted toward (and/ or sprang from) their new status as village patrons. While Indrani and Chandradasa's position allowed them to maintain a high standard of living while still distributing money, in contrast, Rukmini's family's different desires fragmented her savings, leaving little or nothing with which to make a permanent, visible improvement to their living condition. Rukmini faced the unenviable task of budgeting insufficient funds to everyone's dissatisfaction, including her own. Villagers pitied and scorned Rukmini's immediate family for having little besides furniture to show for six years of work abroad. In Rukmini's case, she found it difficult to refuse money to her many deserving and needy relatives and to her demanding husband; few poor village families dared to risk alienating relatives for the sake of their own material prosperity. A burden to the rich, a large and generous family provided a good insurance policy to the poor. 
Family networks directing money from those with surplus to those in need operated to level down migrants' accumulated wealth; only by protecting a moderate resource base could migrants make the leap from a peer among equals to a patron among clients.

Ramesh, Lal, and Chandradasa, three village men associated with female migrants, positioned themselves in radically different roles vis a vis the working woman in their families. Ramesh's drinking, his excessive braggadocio, and his deliberate cultivation of the idle life challenged Rukmini to 'get developed' despite, not with the aid of, her husband. Membership in the drinking group affirmed Ramesh's masculinity, assuage his shame or guilt (lajja) for not 'getting developed', and provide the economic and social community he may have missed in his wife's absence. Chandradasa by comparison found his identity in hard work away from home. The cooperative and trusting relationship he held with his wife gave him control not only of his own salary but also of the money she earned abroad. Willingly remitted for the construction of their house, her pay enhanced both spouses' standard of living and prestigious standing in the village. The avant-garde simpleton Lal, who took on all the 'feminine' chores in Indrani's absence, encountered daily joking comments about his cooking and the laundry with unfailing good humor. Each man asserted his masculinity differently: Ramesh through idleness and alcohol, Chandradasa through work and wealth, and Lal through a humorous, playful self-parodying exaggeration of the feminizing nature of his house-keeping role.

\section{GENDERED POWER DYNAMICS IN THE CONTROL OF REMITTANCES}

When Domestic Work is Taken Out of the Domestic Economy Sold for wages on the global market, the services housemaids 
usually performed at home for free suddenly acquired monetary worth. A commodity on the global market, rendered for strangers, regulated by national and international laws, women's work leapt to the national consciousness. Domestic workers formerly missed in employment surveys became 'our army of housemaids'. Sri Lankan social scientists speculated that through salaried employment women would acquire a certain degree of control over the money they earned, leading, at least in theory, to an increased access to decision-making, power, and authority. R.B.M. Korale noted that the migration of labor provides women with a mobility "unimaginable a few years ago"(1983: 23). He stated,

The economic necessities which fuel these migration flows will alter the social relationships within family units and in society as a whole. It is also expected that the desire for greater independence and participation in the social and economic process by women will be enhanced. The wealth acquired by females and the dependence of other household members on this income, will further buttress their social transformation resulting in greater social and economic rights being granted to females (1983: 23).

Using research done ten years after this optimistic prophecy, I explore in detail the extent to which women gained substantial independence, and the forces militating against dramatic upheavals in village social hierarchies.

Like Korale, I set out to explore the impact of new economic opportunities on gender hierarchies in the village. Understanding the change, and the lack of change, in gender roles, spurred analysis of the nature of women's work prior to the advent of migration to the Middle East. Women have always worked hard for their families. Scholars suggested that world-wide, while women made up 33\% of the official labor force, they did $66 \%$ of all the working hours, they received $10 \%$ of the world's income, and they owned less than $1 \%$ of the world's property (Peiris: 1989) ${ }_{26}$. However, scholars often did not 
count female-gendered tasks as 'work', or count housework as 'employment'; only labor remunerated with wages made a difference in many economic analyses. Korale, who predicted the revolution in women's lives, wrote about migrants, "In the case of females, the majority of returned migrants were housewives when they migrated, and were not really economically active females"(1989: 12). He continued to note that women in the 'role of the housewife' were not 'actively seeking work'. Similarly, D.M. Ariyawansa reported that in a 1988 survey of Middle East migrants, $93 \%$ of the migrant women were 'unemployed/ underemployed' before going to the abroad (Ariyawansa 1988). The gendered division of labor and the accompanying ideology of 'women's work' obscured the role of women in the economy, where they were assumed to be secondary or supplementary earners (Jayaweera 1989). Women's perceived economic 'inactivity' in the literature mirrored not their daily performance, but rather the "Self-interested tailoring of descriptions and appearances by dominant powerholders" (Scott 1990: 54), in this case scholars and policy-makers, who defined and discussed 'work' in such a way that women's contributions disappeared 27 .

Surveys on migration stumbled into murky territory; did the 'reentrant' qualify as a 'housewife' again, or was she 'unemployed'? This semantic difficulty revealed the necessity of incorporating services performed daily by women for their families into a fuller picture of 'work', not only the work of migrants to the Middle East, but also unpaid labor of any individual living in a household, whether male or female. Meillassoux's analysis of primitive accumulation and the subsidy of the capitalist economy by the domestic economy went some way toward an integrated approach to the question of labor. Mary Steedly writes, "By moving (slightly) against the grain of 
official discursive practices I hope to make explicit the necessary exclusions by means of which all narratives... are engendered"(1993: 31). While agreeing that migration may bring about changes in women's positions in the village, I see no one-to-one correlation between wage labor and gender equality. The forces in the village that controlled the fruits of women's work before the advent of migration still operated within households, mitigating social change. The (scholarly) myth of the housewife's economic inactivity was part and parcel of the gendered cultural ideologies that devalued and controlled women's labor.

Taking domestic work out of domestic economy did indeed send a series of shock waves through village social hierarchies, giving migrant women leverage toward gender transformations. Changes stemmed not from the work itself, but from the new meaning of the work. Significance arose not so much from a difference in the services women performed, but from the people for whom they labored and the import attributed to their work and wages. Although cash wages changed the balance of power in the family and community, researchers should recognize that control of the wages fit into other preexistent family structures, which regulated women's work before their migration. The renegotiation of gender hierarchies thus rested not so much on work and wages per se, but on an ideological battle for recognition of what counts as justice, authority, and women's rights.

Village women explicitly equated the work they did abroad 'for the market' with their everyday activities 'in the home' in Sri Lanka. Work abroad gave women no other marketable skills with which to enhance their earnings upon their return, or challenge the gendered division of labor. Poorly paid and not well respected, jobs as domestic servants in Sri Lanka seldom if ever drew village women 
out of their houses. Having taken several days to relax, most women integrated quickly into their former roles, cooking and caring for their family. In her study of Sri Lankan female migrants to Singapore and Hong Kong, Malsiri Dias (1991) suggested women stepped relatively easily back into their household role of wife and mother. During their work abroad, they did not adopted any foreign ways, or assume a different ethnic identity. Although they gained confidence for dealing with crises, women did not go far in rejecting accepted customs, or starting their own businesses, or taking on roles of community leadership. Dias claimed that women took a passive approach, fitting back into their households smoothly.

While Korale's optimistically predicted gender revolution has not yet come to full blossom, I feel Dias' pessimistic portrayal of passive women also oversimplifies changes in practices and ideologies in the village. Despite lack of great changes in their home work environment, I feel that women who made money in the Middle East recognized the worth of their labor, and their rights to its fruits. They came to a certain self-worth and dignity through their jobs that lent them assurance in their struggle for power. Changes in women's social positioning took place not on a tabula rasa, but in the context of pre-existing gender hierarchies and cultural ideologies that discounted women's work to begin with. A situation where many poor women had ready access to gainful employment, while poor men do not, threatened earlier patterns of dominance and subordination and the identity of village men. Mediated by a number of preexisting cultural factors, women's new financial clout did not lead directly to an increase in their authority and decision-making power; change came slowly, balked and barred at every juncture.

In the following section, focusing on the contestation and renegotiation of gendered power structures, I examine three cases 
where husband and wife struggle over the control of remittances. Authority and decision-making as to who spends the wages and how counted as much or more than the labor itself. I explore the ways in which local processes "renewed, recreated, defended, and modified" the lived hegemony of village life in the face of a new economic orientation that "resisted, limited, altered, and challenged"(Williams 1977: 112) it. Absent from the village for long periods of time, migrants often sent their money home to others; village spouses controlling remittances accrue as much or more status from the new wealth than the migrant him or her self. Paradoxically, the 'greater independence and participation in the social and economic process' Korale predicted as a byproduct of migration appears as much or more in village wives of male migrants, as in the female migrants themselves. Despite an influx of money, pre-migration intra-family hierarchies and gender ideologies prove resistant to change. By looking at the incrementally shifting habits and attitudes of ordinary people in their everyday worlds, I explore the rupture and reinforcement of older village practices in flux.

Theft and the Extended Family: Ranjani's House

A tall, thin woman with worry lines beyond her years, Ranjani lived with her grown son and daughter on the marshy back portion of her sister's small land plot. After eight years of work abroad, Ranjani lived in a house she described as "like a kennel where bitches have puppies" ${ }_{28}$, a tiny two-room clay hut with coconut-frond roofing. She said that some women would have drunk poison if what had happened to her had happened to them.

Receiving a piece of land in a government land distribution in 1980, Ranjani and her husband Sarath started building a large house in 1986 with the money she sent home from working for two years in 
Saudi Arabia. Construction continued funded by Ranjani's next job in Jordan. Tension between the couple grew, however, over Sarath's infidelity with a neighborhood woman, and over how to spend Ranjani's remittances. Although Sarath asked that Ranjani not give any money to her parents, she sent them some secretly. Furious when he discovered her deception, Sarath fought with Ranjani's parents; her elderly father's leg broke in the brawl. In 1988, while Ranjani was still in Jordan, her husband sold their house and land for much less than its worth 29 , and bought a second house further from her parents' $\operatorname{land}_{30}$. Having allowed both the bank account and the land to be written in her husband's name, Ranjani had little leverage to prevent the sale.

Upon her return from Jordan, Ranjani said her husband beat her to keep her from being too close to her family, but when he hit her, she ran to her parents. Having burnt her identity card and her clothing, Sarath sold the second house at a $\operatorname{loss}_{31}$, took the money, and left the village to live with his lover. Ranjani met her husband once at a fair after the separation; she told me with pride that she hit him in the face with her umbrella. Despite urgings from her family and friends however, Ranjani refused to go to the courts to claim her half of the money her husband made from selling their house and land. Although she felt others would have attempted suicide in her situation, she said that she did not want anything from him.

After her husband sold their house and left, Ranjani returned to the Middle East. Working two years in Kuwait, she sent her money to her mother, who paid off loans and took care of household expenses. Only a minimal sum remained in the bank when Ranjani returned to Sri Lanka. Ranjani worked another two years in Abu Dhabi U.A.E. with a similar lack of lasting material benefit. In 1994, 
just before I left Sri Lanka, Ranjani got a job in Jordan, from which she vowed she would not return until she had saved enough money to buy some land and build a good house.

Denigrating Sarath with a common trope villagers use to define a wasteful husband, Ranjani said, 'He just sat at home eating what I sent.' This implication of idle consumption fails to capture the extent of Sarath's deeds; jealously eager to accumulate wealth in the form of a luxurious cement house, he also proved capable of squandering Ranjani's earnings on a grand scale. It fell to Ranjani's natal family, not her husband, to spend her earnings for daily consumption. Although Ranjani broke with her husband in order to be able to provide for her family, at the same time she sought at least a minimal personal well-being she had not as yet achieved. Whether women 'got developed' from their work abroad depended to a great extent on the people handling their remittances. Embedded in family networks, women found few if any role models for a post-migration life as an independent individual.

A group of women gathered during one of my several interviews with Ranjani discussed strategies for retaining access to and control over money earned abroad. Many women said they wrote bank accounts and land that they purchased in their own names, despite inconveniences to people at home. All said they counseled future migrants to keep their money with them, only sending occasional gifts for the holidays. Money regularly remitted often vanished before the migrant returned home. Group agreement on ways and means of managing their new financial responsibilities indicated a growing female awareness of power issues central to gender transformations and the control of remittances. However, even these knowledgeable women rarely followed these words of wisdom themselves; other priorities superseded their desire to 
accumulate personal wealth.

Selfishness, Success, and Suicide: Kamala

Five years after Ranjani's dramatic domestic tragedy, a similar situation arouse again in the village area. A young village migrant named Kamala quarreled with her husband over control of three and a half years worth of remittances; distribution of money to the extended family, and a house and land figured in this case also.

When I first spoke with Kamala's mother Caroline in May 1993, Kamala had been in Dubai, U.A.E. for nearly three years. Caroline, a plump and cheerful mother of ten grown children, looked after her daughter Kamala's two sons during the day, and their father Pradeep took them in the evenings. Kamala usually sent all of her money to her husband. Caroline and Pradeep had quarreled fiercely when Kamala sent some money directly to her mother. Resenting both his stinginess and his control over her daughter, Caroline said that although she looked after and fed his children, Pradeep only occasionally gave her money or food items.

In January 1994 Sita and I talked with Caroline again. When we mentioned the Middle East, Caroline started to cry, saying that Kamala, who had returned from Dubai the previous October, had been very ungrateful to her lately. Although Caroline had looked after her daughter's children for three years, Kamala had given her no money and no thanks. Even when Caroline was in the hospital, Kamala had not come to visit. Crying harder, Caroline pointed towards her daughter's house and said that mothers love daughters more than sons; the sons wander away, but the daughters should stay loving. Kamala's behavior hurt her badly.

Three days after we talked with Caroline, Kamala attempted suicide by drinking a poisonous weed killer. While Kamala's children 
stood by bewildered, the neighbor across the street rushed to help. After a ten-day stay at the hospital, Kamala returned to the village and rested with her husband's family. Kamala's mother and father never went to see their daughter in the hospital. Village rumor reported that Pradeep had given Kamala's money to his sister, who had been loaning it out for interest. Although Kamala kept asking her husband get some of the money back so that she could give gifts to her mother and siblings, he kept refusing. At the same time, he took some of Kamala's money from his sister to buy himself a bicycle frame and to drink and smoke ganja (marijuana). Frustrated and furious over the lack of access to her own money, Kamala expressed her despair in a suicide attempt (more on this below).

A month after she returned from the hospital, Sita and I talked with Kamala about her experience in the Middle East. Saying she went abroad 'to get developed,' Kamala mentioned a desire to buy the house they had rented for six years, or build another. Kamala worked for a large family in rural U.A.E., where she looked after nine children, cleaned, cooked, fed the livestock, and did the laundry. In her narrative, Kamala related how she handled several crises arising during her stay in the Middle East, portraying herself as decisive and assertive. After each instance that she stood up for her rights, she claimed her situation improved. Stressing the importance of selfconfidence, Kamala suggested that a fearful attitude towards Arabic employers doomed a housemaid to restricted mobility and slavishly hard work.

In her narrative about life in U.A.E., Kamala painted herself as practical, self-reliant, thrifty and strong. Confronting her employers over unpaid wages and accompanying a neighbor housemaid to the police in a dispute, Kamala portrayed herself as assertive and courageous. Elements of her life in Sri Lanka stood in 
marked contrast; although Kamala had the option to return to work with her former employers, she said her husband would not allow it. Pradeep not only controlled her past wages and regulated her relationship with her parents, he also limited her future work opportunities. Hoping to explore her motivations, I said, "Don't get angry when I say this, but I heard that you drank poison." ${ }_{32}$ Kamala covered her eyes, and did not reply, and Sita gently turned the conversation to more mundane matters.

In Sri Lanka, threats of suicide are common and attempts frequent; in the world Sri Lanka ranks second only to Hungary for suicides per unit of population (Marecek 1993), with both men and women attempting and committing suicide in roughly equal numbers. Writing of suicide as an aggressive act aimed at expressing frustration and at causing mental pain, Jonathan Spencer notes its prevalence in relationships where "The overt expression of anger is quite simply unthinkable"(1990: 186). In Sri Lanka, wives and children cannot freely express anger or frustration against husbands and parents. Seen in relation to her self-portrayal as decisive, independent, and uncowed abroad, Kamala's suicide attempt represents not only the psychological despair of alienated labor, but also the forceful expression of extreme dissatisfaction. Bringing her grievances into the public eye, Kamala's action serious challenged Pradeep's authority over her money, sociability, and mobility. Yet even if Kamala's protest gained her leverage in the struggle for financial control, the ineffectiveness of less drastic measures indicate just how much power gender relations entrenched in the household still retained. Despite Kamala's self-destructive initiative, she never obtained clear control of her money during my stay in the village.

Pradeep and Kamala married for love, against their families' 
wishes. Instead of letting her parents arrange a match, Kamala declared her independence and exercised her right to choose. While in-laws retained a great deal of influence in the lives of couples married 'by proposal', village custom did not sanction their interference in the lives of couples who eloped. Since Kamala had chosen her husband, her parents assumed that his use of her money met her tacit consent. In the village, material gifts sanction and ratify social bonds. For Kamala, the inability to give to her parents on their request became a negation of her social duty to them, a denial of her relatedness, a rejection of kinship, and ultimately a rejection of self. Piecing together information from different more and less reliable sources, I gathered a picture of what Pradeep had done with Kamala's money. Although local gossip implied he had wasted much of what she remitted, a closer look revealed considerable thrift and business acumen. Caroline and Kamala independently confirmed that one year of Kamala's salary went to pay back the loan taken to finance her job. Caroline noted that Pradeep purchased a small cinnamon garden for about Rs. 25,000/ (US\$ 500, or roughly five months' salary). With two months' salary Kamala purchased a sophisticated cassette player which she sent to Pradeep in Sri Lanka. Perhaps the greatest source of tension, Pradeep had lent a further thirteen months' salary (Rs. 65,000 / or US\$ 1300 ) to a neighbor woman of the Berava caste, who promised to pay it back but in early 1994 showed no signs of doing so. Village rumor (perhaps inevitably) suggested a sexual connection as well.

While indiscriminate gifts of money to a low caste lover hardly count as a wise investment of money from the Middle East, the discrete and deliberate acquisition of property through outstanding debt has a long history in the village. Halaagama with financial resources have for over thirty years extended loans to those with little 
prospects of repaying them, in the hope of procuring the mortgaged land deed in exchange. In January 1995 Siri wrote in a letter that Pradeep had taken the deed for the Berava woman's house and land as collateral for the Rs. 65,000/, and had given the neighbor and her elderly parents until the end of 1995 to move out. Their land conveniently bordered the cinnamon land Pradeep had purchased several years earlier. Only one in a long series of caste-based land exchanges related to migration, Pradeep's transaction, if successful, would displace a Berava family of considerable standing and wealth, driven into debt by the reckless spending habits of their son-in-law.

Depending on the success of Pradeep's land-takeover, ${ }_{33}$ using purely material criteria, Pradeep's investments may qualify the family as one that 'got developed' through migration. Pradeep continued to work while his wife was away, seldom turning to drink, and his demeanor in no way suggested a threat from his working wife to his masculine self-image. However, Kamala's estranged relations with her natal family and her suicide attempt reveal serious costs to Kamala and her family network when she felt she did not share a say in the use and distribution of the money she remitted. Although they may rank as 'developed' in the future, the internal struggle for control over Kamala's money nearly tore her body and her family apart.

Six years after Ranjani's husband appropriated the fruits of Ranjani's labor, Kamala faced a similar situation. Well educated, ${ }_{34}$ young, independent, and spirited, Kamala still faced nearly insurmountable resistance to her efforts to control her own money. Alienated from her natal family and prohibited by her husband from returning to the Middle East, Kamala arguably fared even worse than her older counterpart Ranjani. Perhaps the rising expectations of young village women lead them to chafe more at the gendered 
restrictions imposed by their families. This case in particular gives one pause to consider whether the changes in the village have been to the benefit of women.

Simon and Chandrika: Accountability in the Reverse Direction

Having presented two cases where female migrants struggled with their spouses over control of the money they remitted, I now turn to a case where a male migrant sent his earnings home to his wife. During her husband Simon's absence, Chandrika controlled both her own salary and the money he sent her every month. Upon his return, Simon held Chandrika accountable for her use of his money in a way neither Ranjani nor Kamala could hold their husbands.

One of only six village men to work in the Middle East, Simon spent eight years as an exterminator in Saudi Arabia. Simon remitted his considerable salary of Rs. $11,000 /$ a month ${ }_{35}$ to his wife Chandrika. Among the best educated in the village, Simon had completed his A-levels (the Sri Lankan equivalent of high school) while his wife Chandrika held a bachelor's degree from a private school in Colombo. Leaving their young son with Simon's sister, Chandrika commuted to work at an import-export firm in Colombo, supervising the construction of their new house in her free time.

With Simon living abroad, Chandrika held considerable power and authority in the village. Able to trace her descent back to the original foundress nine generations earlier, Chandrika inherited both HH status and land in the heart of Kosgahakanda, near the temple and the oldest and wealthiest neighborhood of the village. Simon's family, also HH caste, also held land in the area. Chandrika gave generously and often to religious and secular festivals. Upon his return from Saudi Arabia, Simon stepped into a leadership role befitting one of his caste and wealth; until his return, Chandrika, 
acting as his proxy, not only headed her own household but also influenced village decisions in his stead. Empowered in his absence, Chandrika lost much of her authority when her husband returned.

My research assistant Sita and I spent a leisurely afternoon in April 1993 talking with Chandrika as she supervised brick laying at her new house ${ }_{36}$. Started in 1991, the large structure occupied land given to Chandrika by her mother. Various items of furniture and household appliances such as a refrigerator, a television set, and a pump for filling an the overhead tank to supply running water to the house were stored at Simon's family house. Chandrika thought that when fully constructed, the house would be worth about Rs. 300,000/ (US\$ 6000 at 1994 rates), not including furniture.

Ebullient over plans to purchase a bus with his savings, Simon returned from Saudi Arabia in July 1993. Disappointed with the slow progress on the house, he began to question his wife concerning her use of the money he had remitted. Things came to a head between Simon and Chandrika in October 1993, with a loud and violent fight. Sita, who lived across the road and heard the argument, told me some of the details. Saying that he had remitted Rs. 2,50,000/ (US\$ 5000 by 1994 exchange rates) to Sri Lanka since he started working in the Middle East, Simon demanded to know what Chandrika had done with the money, and why she had failed to finish their house. Further, he wanted to know what had become of three gold chains and a pair of gold ear studs, altogether worth another Rs. 50,000/ (US\$ 1000 by 1994 exchange rates.) Chandrika's response, that Simon should not ask about 'past things', prompted his reply, 'Without asking about past things, I have nothing to say in the present. Now, what have you done with the money and the jewelry?' Simon showed his sister his accounts, lamenting that he could find no 
trace of the money he had sent home, and that his wife not only refused to talk about the money but also refused to cook his meals. Sita said Simon then 'Got damned wild with Chandrika', and hit her. Crying and screaming, Chandrika shouted that she did not want him as a husband anymore, and threatened to jump into the well. Simon's sister restrained her from this suicide attempt.

Drawn by the noise, several neighbors gathered in the road. Approaching the arguing couple, Sita told Simon and Chandrika that it was not educated to shout at each other in that fashion. Chandrika said Simon had struck her. Sita replied that all husbands were like that, and recommended that Chandrika tell Simon what she had done with the money. Chandrika again attempted to run away, saying that she would kill herself. Stopped by her sister-in-law, she amended her statement, saying she would first kill Simon and then kill herself. Sita stooped to comfort Chandrika's screaming six-year-old son.

Later I asked Sita what she thought had become of the money. Chandrika, who continued with her own job when Simon went abroad, had told Sita that she saved all the money Simon remitted in a bank account, using her own salary to maintain her family. In retrospect, Sita suspected Chandrika had been lying. Chandrika had lent a great deal of money to various people, many of whom had not paid her back. In particular, Sita thought Chandrika had covered a debt of about Rs. 50,000/ (US\$ 1000 at 1994 rates) for a sister, loaning even more to a jobless brother.

In Sita's opinion, Chandrika stood answerable for her use of Simon's money. Although just, such accountability rarely applied equally to men and women; in the numerous case studies with which I am familiar, I never found an instance of a husband beaten by his returnee wife when she found he had wasted her money. By contrast, 
Sita (and numerous other village women) found Simon's violent assault well within the range of appropriate masculine behavior. Chandrika's story and Kamala's case above illustrate, both the accused and the accusing women threatened or attempted suicide to express their emotional displeasure and distress. Kamala swallowed poison in her frustration and rage, as Chandrika threatened to jump in the well in her panic and (possibly) guilt. In both cases, village cultural habits channeled women's violent emotions inward against their own bodies, instead of outward against their husbands'. Kamala attempted suicide because Pradeep wasted her money; Chandrika threatened suicide because she wasted Simon's money. Both women turned violence against themselves in an effort to express anger against their husbands.

While village culture condemned violence, drunkenness, and wasting money, sanctions against women far exceeded sanctions against men. Tacit approval of self-centered and unrestricted male behavior contrasted markedly with the restraint and control required of women. Despite Chandrika's high status in the village, her education, job, and control of family money, she stood at a disadvantage in her struggle with Simon. Cultural habits held her doubly accountable for not wasting her husband's money, and also legitimated his physical assault.

The new meaning attributed to women's work affected not only gender relations but also patterns of family and caste association. In a close-knit kin community relatives claimed mutual access to assets, and family obligations operated to 'level out' differences in material and economic well-being. Those who accumulated significant assets without redistributing their wealth to poorer relatives made choices about which of their kin ties to sustain on their way up the ladder, and which of their ties to abandon. The 
continuation and abrogation of kin ties had direct impact on shifts in caste and sub-caste relations. Representing a division of caste by wealth, the highest grade in the Halaagama caste retained only those who maintained social standing and wealth; poorer relatives and families who lost respectability through 'incorrect' marriages dropped to the lower grade. All villagers strove to maintain 'far' kin links with rich and respectable relatives, while distancing themselves from associations with poorer but 'closer' relations 37 . As women negotiated their relations with the person or people who saved and spent the money they remitted to Sri Lanka, they also challenged and changed relations fundamental to 'family' and 'village'.

In a society dependent on the extended kinship system, many people had claims on money migrants earned. Ranjani, Kamala, and Chandrika fought bitterly with their husbands over who had control over the fruits of labor abroad. In all three cases, the men sought to consolidate remittances by investing in a house. The violence Sarath and Pradeep deployed to try to separate their wives from their families, and Simon's rage over Chandrika's gifts, could be read in two ways; although conforming to classical definitions of abusive and controlling husbands, it also indicated an awareness of the risks of becoming too firmly enmeshed in a large and impoverished extended family. Kamala broke with her family but kept her husband (and thus indirectly the money he appropriated from her). Ranjani broke with her husband but kept her family, implicitly consenting to the bonds of kinship that demanded all of her earnings be spent for family consumption. In a kin group of such size and poverty, distribution of remittances results in a leveling down of the migrant's social position. Ranjani firmly vowed that 'this time' she would save enough money to put up a house. It remains to be seen if that will be 
accomplished.

\section{UNMARRIED MIGRANTS}

While in the previous section I examined relations between migrants and their spouses, in this section I focus on relations between unmarried women and their natal families. Examining accountability, cooperation, and access to money, I explore the impact of wage earning on marriage arrangements and gender transformations in the family and village.

Although the majority of women migrating from the village were married, a significant minority of unmarried women also went abroad to work. Many with conservative opinions about the advisable roles and activities of unmarried 'girls' counseled against work in the Middle East, claiming that a respectable family arranging a marriage for their son would retract a proposal if they discovered the woman had worked as a housemaid or as a factory worker in the Colombo Free Trade Zone. A number of fathers with adult, unmarried daughters emphatically condemned out of hand all jobs requiring extended stays away from home.

More pragmatic villagers noted that a woman returning from abroad with significant savings offered as a dowry had little difficulty finding eligible suitors. In the presence of money, and in the absence of proof of immodest sexual behavior abroad, good arranged marriages for unmarried migrants often created permanent upward mobility for their families. As more women, both married and unmarried, ventured abroad, and as villagers of all castes and statuses became more familiar with the phenomenon, the stigma attached to migration decreased.

Claiming that parents often wasted less money than husbands, Milton, a local sub-agent, thought that unmarried women 
often fared better than married ones when they migrated. Although educated parents especially looked after their daughter's fortunes, Milton noted that educated families sent few women abroad. Only poor and uneducated people with poor and uneducated daughters took the Middle East option. While my research confirmed Milton's statement by showing that wealthy, educated, HH families sent no women (married or otherwise) abroad, many of the unmarried migrants of poorer families had done well in school, and their work often improved the family living situation immensely.

\section{Remitting To Fathers: Premasiri's Daughters}

Siri and I found Premasiri sitting in the dappled morning shade on the cement border that surrounded his spacious five-room tile roof house, peeling cinnamon for a local land holder. He and his eighteen-year-old youngest son, who scraped the hard green outer layer off the sticks before his father stripped them of their rich, red, inner bark, welcomed our interview wholeheartedly as a chance to chat while working. Considered by many villagers as a family much 'improved' through migration to the Middle East, three of Premasiri's five daughters had worked abroad, with two leaving before they married and all three remitting their money to their parents. A tall, lean man in his fifties with graying hair, Premasiri said that he took good care of the money his daughters sent from the Middle East, declaring that he had not wasted any of it, "Not even five cents." 38

Premasiri's family (HKK) bought their land from a Berava family in the early 1960's. Until 1988 they lived in a small house, which they enlarged and improved. In 1988 they paid to bring an electricity line down the road to their house, a luxury few except the wealthiest in Kosgahakanda could afford. Recently they added several rooms on the back side, and removed and replaced the roof. 
In 1993 they constructed a carpentry workshop at the back of the property. Premasiri's daughter Lalita's husband needed electric tools for his work, but the house where he lived had no power lines.

The first in her family and one of the first in the village to go to the Middle East, Lalita, Premasiri's third child, spent nearly six years abroad. Paying an agency only Rs. 675/ (approximately US\$ 40) in 1978 for a job in Dubai UAE, she earned Rs. 3,200/ (approximately US\$200) 39 a month. Eighteen years old and unmarried when she left, Lalita stayed abroad for three and a half years. With the money Lalita remitted to a bank account in her mother's name, her family bought two acres of cinnamon land. Well tended, the land lucratively supported a family. By peeling their own cinnamon, Premasiri and his son earned even more per acre than other landed proprietors, who had to share their profits with their peelers. Premasiri's cinnamon estate adjoins that of several wealthy HH caste Kosgahakanda landlords.

After her return from Dubai, Lalita spent two years in Jordan, receiving a free ticket from her sister Sita, then also working abroad. Lalita made Rs. 3,000/ (approximately US\$ 125 at a 1981 exchange rate) per month, for a total of Rs. 76,000/ (approximately US\$ 3150 at a 1981 exchange rate) $)_{40}$. Anticipating her return, Premasiri and his wife arranged a marriage. They chose a hard-working young man who had done some carpentry for the family. The boy's mother was from the Para caste (Pariah or Untouchable), his father HH. The Para shadow on his social standing matched the intimation of disrespectability from Lalita's years abroad. At the same time, his industry and work ethic recommended him, as her dowry recommended her. Despite their daughter's wealth, Premasiri and his wife chose a hard-working son-in-law of mixed caste, rather than 
making a higher-status but less skilled match. Their choice indicates that they value employment and future financial security over an increase in caste status.

Lalita received Rs. 40,000/ (approximately US\$ 1670 at 1983 exchange rates) in cash and Rs. 20,000/ (approximately US\$ 830) worth of jewelry and furniture as a dowry from her parents, or about $80 \%$ of the money she earned abroad on her second trip. Premasiri reminisced about the wedding ceremony, which went on for five days and cost nearly Rs. 75,000/ (approximately US\$ 3125 at 1983 exchange rates). Both the size of the dowry and the magnificence of the ceremony and following celebrations enhanced the status of the new couple and their families.

I did not ask about ownership of the two acres of cinnamon bought with Lalita's wages from her first job abroad, but I believe Premasiri held it in his name. Whether Lalita would inherit it after her parents' death, or whether it would be split equally between the siblings remained to be seen. Whatever the arrangement, it seemed to please all parties, judging from the high degree of cooperation in the family; they roofed Lalita's husband's new carpentry workshop, built on Premasiri's property, with tin sheets salvaged from an old house of Lalita's sister Mangali, also working abroad. Money and goods seemed to flow in abundance between family members, without an exact tally of worth and debt. Premasiri's investments ensured enough wealth for all those in his extended family, also making him a patron to some of his poorer relatives.

Mangali, Premasiri's eldest daughter, went abroad in 1987, after her arranged marriage, leaving her husband and one-year-old daughter to live with her parents. Her work in Lebanon disrupted by the war, Mangali returned home, purchased a ticket, and went to 
Jordan to work as an attendant in a private hospital, earning roughly $\$ 200$ a month. She sent her money to her parents, who bought a block of land with a house from a drummer family in Polwatta, and replaced the coconut frond roof with tin sheets ${ }_{41}$. Mangali's husband, who had no job of his own and lived with her parents, had a series of arguments with his in-laws, left his children, and took up with another woman. Premasiri described several fist- and knife-fights, and waxed poetic on 'that useless dog', claiming his son-in-law had started working for an illicit liquor brewer and had sold kasippu out of the new house in Polwatta until they evicted him.

Of the money Mangali had remitted, Premasiri said he had spent over Rs. 100,000/ (US\$ 2000 at 1994 exchange rates) to build a new cement house on Mangali's property, still unfinished. Having returned briefly to Sri Lanka, Mangali again went abroad as a housemaid, remitting her salary every three months to her parents. Keeping most of the money in the bank, Premasiri said he used some of her earnings to feed Mangali's children and to continue construction of the new house. With a good cement house and money in the bank, Mangali would be able to remarry, or remain single, as she saw fit.

Premasiri's family did very well sending women to work abroad. With Lalita's income, they purchased two acres of cinnamon, putting them among the largest landholders in the village area. By financing jobs with family money, Premasiri's daughters never fell into debt to the moneylenders, but kept their profits in the family. The family prospered and grew closer by following Premasiri's lead; however, Mangali's husband broke ties with the family. Jobless and without authority, he rebelled against the rule of his father-in-law. Perhaps feeling emasculated by his dependent position, he, like 
Rukmini's husband Ramesh, turned to alcohol and alcohol

production. Abandoning his share of his wife's upcoming fortune and severing all bonds with her family, at the time of my fieldwork he lived with his second wife and harassed his mother for money. Control over women's remittances affected not only male-female relations in the village, but also male-male relations. While Premasiri's status as a patron rose markedly with his control of his daughters' wealth, his doubly disenfranchised son-in-law lost standing twice, first with respect to his employed wife, and second with respect to the father-in-law managing the money.

Mahinda's Elopement: Women Marrying Men of Their Own Choice

While women with good relationships with their families often profited by allowing their parents to arrange a marriage for them, women who chafed against their parents' authority found freedom through choosing their own mates. Unmarried migrants at odds with their parents or not receptive to arranged marriages either eloped with men of their own choice, or renounced matrimony entirely. Their financial independence gave them more authority in making their decisions.

In mid-January 1993 Mahinda, the eldest son of a poor HKK family in Kosgahakanda, eloped with a neighbor's niece. Her father, hoping for a better match for his daughter, who had just returned from the Middle East, chased the couple, trying to catch them before they had 'lived as husband and wife' and separate them by force. Having hoped to arrange a marriage for Mahinda, his family also disapproved of the love match.

Several days after the elopement, my research assistant Siri met Mahinda at the junction in the evening. Offering him a cigarette, and calling him a bridegroom, Siri asked what business brought 
Mahinda to the market area. Sitting astride his bicycle and checking frequently over his shoulder, Mahinda replied that he had sent a message to his mother, and feared that his father might intercept it and come in her stead. Legally married, the new husband and wife had accepted an invitation to dinner at Mahinda's father-in-law's house. To keep their self-respect, they felt they needed to arrive at the house by car, but after a small wedding party and registration fees, they had exhausted all of their money. To hire a car, Mahinda asked money in secret from his mother. Later that evening Siri saw mother and son talking, and money change hands.

When I interviewed Mahinda a month later, his wife had found another job abroad. Borrowing Rs. 13,000/ (approximately US\$290 at 1993 exchange rates) to pay the job agent, she left to work for two years as a housemaid in Kuwait. Mahinda said that his wife's parents had used all of the money she earned abroad, wasting much of it. 'She had nothing left when I got her,' he said, except for Rs. 3,000/ (approximately US\$ 67) that they spent on the wedding. Before they married, she had told Mahinda she planned to go back to the Middle East. Until his wife returned, Mahinda planned to stay with his parents.

Later I asked Siri why the couples' respective parents were so upset with the love match. Noting that when an unmarried daughter goes to the Middle East her parents take out loans for her, Siri suggested that the bride's parents expect to use some of her money for house-development or land purchase in exchange. A daughter should only marry after spending for her parents. In addition to the money issue, Siri noted that Mahinda had no steady job, and neither bride nor groom owned property. Observing the couple's youth, Siri predicted a dearth of long-distance planning and asked, 'What do they know about the world?' 
Not having spoken with Mahinda's wife or in-laws, I cannot speculate on the justice of Mahinda's claims that they wasted her money. Whatever the prior situation, Mahinda's bride found herself in the unenviable position of starting afresh, taking loans to finance her third job abroad rather than using her savings to pay the agency. During the year following her departure, Mahinda held no steady job, but spent his time with another young migrant's husband, telling jokes and smoking cigarettes at the junction. Neither man's wife sent him money during that time, though both husbands accrued considerable debts they promised their wives would repay. Mahinda's wife escaped what she must have seen as the trap of her parents' control by marrying, thus ensuring she could manage her own money. At the same time, future relations with her husband, especially those pertaining to administering her money, remained open to negotiation.

While Mahinda's wife chafed at parental control, Premasiri's daughters did very well by letting their father control their remittances. Mahinda's wife married a penniless, jobless young man without her parents' permission. In contrast, Premasiri and his wife arranged good marriages for their daughters, ensuring that their husbands had good jobs and stable characters. While Mahinda's wife had no assets to her name when she went abroad for her third job, Premasiri's daughters had all acquired houses and land. In Premasiri's daughter Mangali's case, where a proposed marriage failed, her father continued to look after his daughter's finances, children, and house. By marrying for love, Mahinda's wife renounced her claims to all such help from both her parents and his. In these cases as in others, 'getting developed' depended not only on the industry of the migrant, but also on the wise investments of the people at home receiving and managing her remittances. While a family working in harmony could work miracles with the incoming money, women from families at 
odds with each other found it difficult to control their money and 'improve'.

\section{FLEEING: OTHER MOTIVES AND MEANINGS FOR}

\section{MIGRATION}

Although many migrants worked abroad purely for the money, others left the village because of the 'push' of their social situation at home or the 'pull' of new destinations. In the following two cases, I examine alternative motivations for migration, above and beyond the wish to 'get developed'.

Dreaming of Travel: Shriyani in Austria

Of all the village women with whom I spoke, Shriyani was the only one to say that she had gone abroad primarily in order to see new places, meet new people, and learn new languages. Ever since she was fifteen, it had been her dream to travel. An unmarried middle daughter in a family of seven, Shriyani worked as a housemaid in Pakistan for 4 years. She then went to Jordan, where she worked for a year and a half. In February 1993 she left Jordan to go to Vienna, Austria, to work first as a housemaid and later as a nursing-home assistant.

Shriyani's parents had recently purchased and renovated a three-bedroom cement house with a tiled roof. Their large garden contained numerous unusual plants, and they had a well and a toilet (both signs of affluence in the village area) on the property. The house had electricity, and Shriyani had brought a large television to complete the lavishly furnished living room. Unusually dressed in white cotton pajamas and a blue and white bathrobe, Shriyani spoke with Sita and me at length, in English, when she came home for the New Year holiday in April 1994. The most significant festival of the 
Sinhala year, New Year saw many migrants returning to the village for at least a month's vacation. 42

Shriyani came the closest of any village woman with whom I talked to voicing what might be called explicitly feminist ideas. Describing herself as 'a lot like a man,' Shriyani said that she did the adventurous, away-from-home things that men often did, that her hair was short, that she preferred to wear trousers. Because people in Sri Lanka 'had different ideas,' she tried to tell them what life in Austria was like. For instance, her mother often told Shriyani not to walk alone in the village. Shriyani said that even before she went abroad she thought such rules were 'nonsense', and she often fought with her parents about them. Elaborating on her masculine skills, Shriyani mentioned that in high school she captained the debate team, and as a child, she used to ride a bicycle (an activity reserved largely for men). I asked if she could swim, and she replied, 'Yeah, sure.' Most village women (and even some men) could not. In Austria, despite hard work and racism, she found a freedom and acceptance unattainable in the village.

Remitting most of her surplus salary to her parents in the village, Shriyani portrayed herself as a selfless daughter. While in Austria, Shriyani dreamed that her parents had died. Feeling afraid, she wanted to return home immediately. She claimed she worked hard not for personal riches, but to provide her family with enough that they need not suffer. In her youth, Shriyani remembered that her parents always saved her a bit of food to eat before school, even if it meant that her father himself had to go hungry ${ }_{43}$. Unlike some of the greedy Sri Lankans she had met in Austria, Shriyani said that she did not want much for herself; she wanted her family to be able to live without borrowing from anyone. 
Looking over her shoulder and remarking that it was good her parents spoke no English, Shriyani told Sita and me that she planned to stay in Europe for the rest of her life. Thinking she slept, her parents had discussed arranging a good marriage for her in Sri Lanka. They were anxious because she was nearly twenty-eight years old. Without explicitly telling them her long-term plans, she later assured her parents, 'I'll take care of myself, don't worry.' Caught between two Sri Lanka and Austria, Shriyani felt she could no longer consider marrying a Sri Lankan man or settling down in the village. Although Shriyani's family had certainly 'gotten developed' through her and her sister's work abroad, Shriyani's migration experiences abroad made her prefer a semi-permanent voluntary exile from the land of her birth. Despite her love for her family, the values of female independence that attracted Shriyani to Europe in the first place left her few viable options to settle in the village.

Burnt and Beaten: Winitha's Escape

Unaddressed in formal accounts of migration, flight from domestic violence motivated a number of village women in their choice to seek employment in the Middle East. In a number of cases, women deserted during their time abroad by their husbands found relief, not tragedy in the end of their marriages. Despite the difficulties of living alone, they felt their new independence preferable. Official pronouncements and national news items about the adverse effect of migration on marital unions rarely took into account the pre-migration quality of the relationship.

One day in late December 1992, when Siri, his wife Telsie, and I were returning along a back road from Siri's cinnamon estate, a woman with a small child in her arms approached us tentatively and asked Siri if he would read to her a post card in English from a 
Colombo job agency, which informed her that she had been selected for the post of housemaid, and that she should come to the agency immediately. Winitha had four children, the youngest just over a year old. She had been in Kuwait when the Gulf War broke out, and although she had managed to pay off her loan, she returned with absolutely nothing else, 'Not even a dress or a biscuit for my children'. As she told us this story, she started to cry.

On our way home, Siri told me that Winitha's husband, Sunil, could peel cinnamon but instead worked with the local illicit liquor producer and spent a great deal on alcohol while his children went hungry. Siri and Telsie speculated on two motivations for Winitha's migration: to alleviate poverty, and to escape a husband who drank and hit her. Telsie, who taught Winitha's eldest daughter at the local school, claimed to have seen burn-marks on Winitha's arms where her husband had hit her with the fire-wood from the cooking hearth. Siri said that most nights the children stayed at the house next door for fear of the father, and Winitha stayed with her sister in a nearby village. With no money for herself, no food for her children, and problems from her husband, migration to the Middle East represented Winitha's best option.

Several days after meeting her on the road, I spoke with Winitha about her upcoming job as a housemaid in Abu Dhabi U.A.E. Winitha planned to stay abroad for three or four years, hoping to pay back her loan and then earn enough money to build a new house. The packed-earth floor of the damp mud house where she lived got muddy when the land flooded in the monsoon season. Keeping most of her wages in the bank, Winitha expected to send some money to her husband's mother, who would look after her four children while Winitha worked abroad. Asked what her husband Sunil thought of her new job, Winitha replied quietly that, although 
he anticipated money with pleasure, two days earlier he had gotten very drunk and broken all the clay cooking pots in the house.

Winitha made some polite gestures for us to please speak softly and change the subject; Sunil, drunk on the bed in his front room, could overhear our conversation even from the front entrance of the neighbor's house where we sat talking.

Winitha went abroad in February 1993, and during my stay in the village, she sent a number of large checks home. Siri reported that in late May 1993, Winitha sent Rs. 11,600/ (approximately US\$ 230) to her brother-in-law, a reliable painter, asking him to repay some of her loans. Sunil went with him to Colombo to cash the check, and they fought over the money. The brother-in-law gave Sunil all the money except a small sum he needed to cover his expenses for travel and buy something for the children. Instead of settling with the moneylenders, Sunil purchased eight or nine bottles of arrack and drank with his friends ${ }_{44}$. Telsie mentioned that by October, Winitha's daughters no longer attended school. In January 1994 a relative of Winitha's said that she had recently sent Rs. 13,000/ (approximately US\$260). One of Sunil's friends went with Sunil to change the money. He gave Sunil Rs. 4,000/ (US\$ 80) and gambled with the rest. The loans still had not been repaid in full, and all four children, sick with fever, needed worm medicine. Since Sunil rarely gave his mother money to take care of his children, Sunil's sisters' families provided as best they could. When I left Sri Lanka in April 1994 the situation remained unchanged.

Women migrated to the Middle East with a variety of different motivations. In Winitha's case, the need to leave was greater even than the goal of earning money for land and a house. In the Middle East, women were sometimes confronted with grueling labor, 
beatings, burns, even rape. But many found work abroad safer than the village, where they might face similar treatment; paradoxically, the Middle East provided them a refuge from the home. Although some felt Winitha had abandoned her children to a fearful and hungry existence, she had succeeded in saving herself from the same. The money she remitted to the village had not yet gone towards rebuilding the house as she had hoped, but Winitha had successfully accomplished several of her main objectives merely by leaving.

Never confronting her husband directly or challenging his authority, she nevertheless curtailed his power over herself by leaving, sending back money she hoped would, at least in part, benefit her children.

\section{GENDER TRANSFORMATIONS}

In these case studies, I try to show through women's own stories how they contest power relations in the village. "Even so, readers should not mistake these representations of others' speech for the actual presence of other voices in this text, any more than they should regard the stories themselves as unmediated and disinterested accounts of 'real' experience" (Steedly 1993:37). In choosing stories to relate, I called on both the exemplary and the extraordinary, trying to create a narrative impression of both the taken-for-granted world and of instances where contention questioned and challenged sedimented behavioral patterns in the village.

Images of women have literally changed through their migration. In the midst of our interview, Premasiri sent his son to fetch a large, framed picture of one of his daughters, taken in a Jordanian studio, posed with a backdrop of Grecian columns. Before the burgeoning of the migration of labor to the Middle East, nearly all the large studio photographs found in village houses depicted couples on their wedding day, with smaller snapshots capturing the wedding 
ceremony and celebrations. In 1994, most migrants' houses contained a photo album, often filled with scenes from abroad: housemaids in veils and long dresses, smiling Arabic children, foreign houses, and exotic landscapes. Sent from abroad to make the strange familiar, these pictures occupied the same physical space as marriage photos in village houses. The photographs from the Middle East, however, emphasized a woman's work instead of her marriage, picturing her as an individual in service, not as half of a couple.

This paper notes that transformations in gender relations do not necessarily correlate in predictable ways with social change, and questions the subtly persistant assumption that change always happens for the better. Migration provides the economic wherewithal for women to stake claims (albeit rigorously contested) to status and decision-making power by revaluing women's work. Although migration has revolutionized earning patterns in the village, however, money continues to flow largely through male hands, and although migration allowed women to escape untenable home situations, their escape did little to challenge the larger village structures of ideological and physical violence that subjugate them. New meanings and values arising from female migration abroad contest with unequal relationships embedded in older village categories.

Villagers negotiated not only their standing in the prestige system, but also which system of prestige to join at any one time among the many operating simultaneously in the village. Tacking back and forth between older and newer forms of power and authority, migrants and their families sought to maximize their own rank and standing. Both the players and the playing field shifted regularly in the village status arena. Using multiple hierarchies and multiple methods to evaluate standing, villagers jousted for status in many different arenas simultaneously; gender hierarchies were 
enmeshed within systems of kinship, religion, caste, and wealth.

Social change and mobility depended not only on progress and development within a given system, but also on the relative dominance of different competing systems in the village. Individuals and families positioned themselves with respect to the multiple intersecting identities and oppressions, searching to find, and to legitimate, the system offering them the most upward (or the least downward) mobility.

Holding a series of priorities in mind, women migrants set forth not only to 'get developed' by earning money for a house and land, but also to feed their families, earn dowries, see the world, and sometimes to escape abusive husbands and dominating fathers. Rarely do women explicitly voice expectations of increased individual power and authority as motivations for their migration. Embedded in their families, women's 'development' depends in large part upon the investments of the relative receiving the money she remits from abroad. Until many path-breakers legitimated roles for independent women in the village, each migrant would strive anew to carve out her own sphere of influence within the enmeshing power structures of her own family.

Both cooperation and struggles between husbands and wives, parents and daughters, reveal sites of collaboration and contestation, as the changing dynamics of women's work give them increased say in team efforts, as well as increased leverage in confronting preexistent hierarchical gender structures. Multiple arenas of negotiation and contestation over power and identity surround migration in Kosgahakanda. Sri Lanka's 'army of housemaids' fought innumerable individual battles, as women negotiated an acceptable new gender hierarchy within a changing social sphere. 


\section{BIBLIOGRAPHY}

Ariyawansa, D.M. Report of the Survey on Changes in Ecomonic and Social Status of Expatriate Labour for Unskilled Occupations. ms. Economics Department, University of Kelaniya, Sri Lanka. 1986.

Bourdieu, Pierre. Language and Symbolic Power. Cambridge: Harvard University Press. 1991.

-----. Outline of a Theory of Practice. Cambridge: Cambridge University Press. 1977.

Brochmann, Grete. Escape Route to Dependency? Female Migration from Sri Lanka to the Middle East. Oslo: International Peace Research Institute. 1987.

Dias, Malsiri and Nedra Weerakoon-Gunawardene. Female Labour Migration to Singapore and Hong Kong: A Profile of the Sri Lankan Housemaids. Ms. Colombo: Centre for Women's Research. 1991.

Fekjaer, Hans Olav. Alcohol and Illicit Drugs: Myths and Realities. Colombo, Sri Lanka: IOGT Alcohol and Drug Information Centre. 1993.

Gamburd, Geraldine E. The Seven Grandparents: Locality and Lineality in Sinhalese Kinship and Caste. Diss. Columbia University, 1972. Ann Arbor: UMI, 1972.

Gamburd, Michele R. Taking Fire under the Water: Labor Migration and Social Transformation in a Sri Lankan Village. Diss. University of Michigan, 1995. Manuscript.

Gunatilleke, Godfrey Ed. "Sri Lanka." The Impact of Labour Migration on Households: A Comparative Study in Seven Asian Countries. Tokyo: United Nations University Press. 1992. 227-263.

Herath, K.M.K.P. "Monthly Statistics on Labour Migration: October 1993." Ms. Colombo: Sri Lankan Bureau of Foreign Employment. 1993.

Jayaweera, Swarna. "Women, Skill Development and Employment." Colombo: Institute of Policy Studies. 1989.

Korale, R.B.M. "Migration for Employment ot the Middle East: Its Demographic and Socio-Economic Effects in Sri Lanka." Colombo: Ministry of Plan Implimentation. 1983. 
Lanka." Ms. 1993.

Peiris, Kamala. "Poverty, Income and Women." Ms. Colombo: Institute of Policy Studies. 1989.

Ratnapala, Nandasena. Alcohol and People. Ratmalana, Sri Lanka: Sarvodaya Research. 1985.

Ryan, Bryce. Caste in Modern Ceylon: The Sinhala System in Transition. New Brunswick: Rutgers University Press. 1953.

Scott, James C. Domination and the Arts of Resistance: Hidden

Transcripts. New Haven: Yale University Press. 1990.

Spencer, Jonathan. A Sinhala Village in a Time of Trouble. Delhi: Oxford University Press. 1990.

\section{Steedly, Mary Margaret. Hanging without a Rope: Narrative Experience in Colonial and Postcolonial Karoland. Princeton: Princeton University Press. 1993.}

Wansekara, W.M.V. Migration Statistics of Sri Lanka, 1985-1992: Country-wise Report. Colombo: Sri Lankan Bureau of Foreign Employment. 1993.

Williams, Raymond. Marxism and Literature. Oxford: Oxford University Press. 1977.

${ }_{1}$ This research was made possible in part by NSF grant number DBS 9207143. Special thanks are due to Bridget Hayden and Lessie Jo Frazier for their comments and suggestions on an earlier draft of this paper. ${ }_{2}$ The outmigration represents $2.7 \%$ of the national population of 18 million persons. See Herath (1993), Wansekara (1993).

3 I have used pseudonyms for both village and individuals in an effort to protect the privacy of the people with whom I worked. ${ }_{4} 48$ out of 161 households contained current or returned migrants.

${ }_{5}$ Sinhala speakers distinguish between long and short soundings of seven vowels. I represent long vowels by doubling the short vowel symbols. ' $i$ ' is a short vowel similar to that in American English 'bit'; 'ii' is similar to the vowel in the English 'deed'. 'e' is halfway between the English 'bet' and 'bait', but without the glide found in 'bait'. 'ee' is similar to the vowel in 'raid', again without the glide. 'ae' and 'aeae' are similar to the vowel in 'cat'. I use the symbol 'a' for the vowel sound similar to the last vowel in 'sofa'; the corresponding long vowel, 'aa', is rarely found in Sinhala, except in the occasional English loan-word, where it sounds like the vowel in 'bird'. 'a' is like the vowel in 'hot', while 'aa' sounds like the first vowel in 'father'. 'u' is like the vowel in 'shoot', but shorter and without the glide, while 'uu' sounds like the vowel in 'food', but again without the glide. 'o' is similar to the vowel sound in 'coat', but shorter and without the glide. 'oo' sounds like the vowel in 'load', without the glide.

Many of the consonants in Sinhala correspond to those used in American English. However, Sinhala-speakers distinguish between to 't-like' and two 'd-like' sounds. I use 'T' to represent a sound pronounced just 
slightly further back in the mouth than the first consonant in the English 'taxi'. I use 't' to represent a dental stop consonant pronounced with the tongue positioned for the first consonant in the English 'thin', but without the passage of air. Similarly, the voiced sound 'D' corresponds with the first consonant in 'dog', pronounced in the same place as ' $\mathrm{T}$ ', with the tongue slightly further back in the mouth. ' $\mathrm{d}$ ' is pronounced in the same place as ' $\mathrm{t}$ ', with the tongue just behind the upper teeth. Sinhala speakers also distinguish between 'full nasals' and 'half nasals' or 'pre-nasals'. The full nasals ' $m$ ', ' $n$ ', and 'ng' correspond to the first consonants in the English 'mood' and 'noon' and the 'ng' in 'sing'. The half-nasals ' $\underline{m}$ ', ' $\underline{n}$ ', and 'ng' occur only before the voiced stop consonants ' $b$ ', 'd', 'D', and 'g', and are kept short and released quickly. Finally, Sinhala speakers note a difference between single and double consonants; 'kk' is pronounced as in the English 'book keeper'.

I have transliterated personal and place names according to the most common traditional conventions, which do not always correspond to the orthography I have set out here.

6 The Kosgahakanda area has two main castes, the Halaagama (Cinnamon Department) caste and the Berava (Drummer) caste. The Halaagama are divided into four sub-castes or grades, two of which, the Halaagama Hewapanna (hence $\mathrm{HH}$ ) and the Halaagama Kurundu Kara (the lower of the two, hence HKK) are represented in the village area (see G. Gamburd 1972). Third from the top in the overall standing of castes in Sri Lanka, the Halaagama far outrank the Berava, who are listed near the bottom of the caste hierarchy (Ryan 1953).

7 diyunu une naeae.

8'Nikang inna vaa, bona vaa, naasti karanavaa.'

9 'PoDi karanavaa, naasti karanavaa, bonavvaa.'

10 'Nikang innavaa, bonavaa, naasti karanavaa.'

${ }_{11}$ I found out in January 1995 that Rukmini had indeed returned to the Middle East.

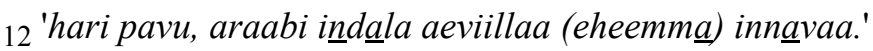

${ }_{13}$ This style of drinking was also prevalent among some Westernized elites; I once attended a dinner party where I learned that respectable unmarried women rarely lingered at such functions past seven or eight in the evening. While their wives huddled together in one room, married and unmarried men drank bottle after bottle in another, until, nearing ten or eleven in the evening, the host decided to serve dinner. Immediately upon eating, the visitors departed, most in cars driven by drunken guests.

14 See Winitha's case, below.

${ }_{15}$ In 1993, a bottle of the officially distilled arrack cost Rs. 118/, while a laborer's daily wage was between Rs. 100/ and Rs. 125/. A bottle of kasippu, a fruit-, yeast-, and sugar-based fractionally distilled moonshine, cost about Rs. 60/.

16 'Course ivara da? ?'

17 In the village where everyone knew all the gossip about everyone else, there was not even the hint of a rumor suggesting that Lal might be actively homosexual. Several other men were known to be so.

18 I interviewed Lal on 31 October 1993; the JP and Graamaseevak $\underline{a}$ interviewed him on 3 November 1993. I do not discount the possibility that some information inadvertently divulged by Siri or myself prompted the village notables to inquire into Lal's personal life.

${ }_{19}$ In Sri Lankan English, 'peon' carries much less of the derogatory tone it has in American English. An office peon runs errands, makes tea, sorts mail, and performs other menial tasks.

20 'Gini penellin baeta kaapu miniha kanamaediriyaTat bayayi.'

21 'savahaal dana shaalaava' 
22 'pansala' and 'deevaalay $\underline{a}$ '.

23 'pin'

24 See G. Gamburd (1972: 354) for more on rank changes through prestations at ceremonies.

${ }_{25}$ Assuming Chandradasa and Indrani were probably funding the construction, Siri speculated that the house would pass back to Lal's brother's family after Lal's death.

${ }_{26}$ Kamala Peiris quotes her statistics from CENWOR, U.N. Decade for

Women: Progress and Achievements of Women in Sri Lanka, Colombo:

Karunaratne and Sons Ltd.

${ }_{27}$ See James Scott (1990: 52-55) for more on euphemisms. Like any

unbalanced diet, consumption of a language deficient in women supports an entity that legitimates their exclusion. (See Bourdieu 1991).

${ }_{28}$ Balu paeTáv daana geyak vagee.

${ }_{29}$ Sarath sold the house, land, and Rs. 30,000/ worth of unused building materials for a mere Rs. 70,000/ (approximately US\$2000 at 1988 exchange rates).

30 Sarath bought the new house for Rs. 47,000/ (about US\$ 1350 at 1988 exchange rates).

31 Sarath sold the second house for Rs. 30,000/ (about US\$ 850 at 1988

exchange rates) to a woman who had been working in the Middle East.

32 'Kivva Ta tarahaa venna epaa; maTa aaranchi unaa Kamalaa-nangi vaha

biuvvaa kiyalaa'. "Don't get angry when I say this" is a common preface for slightly too personal a personal question.

${ }_{33}$ In June 1995 Sita wrote to say that the neighbor had pawned the same land deed twice, once to Pradeep and once to a HKK boutique owner. It was unclear who held the legal rights to the land.

${ }_{34}$ Kamala completed her O-level (tenth grade) exams, which take place after ten years of schooling in the British and Sri Lankan system. This educational level put Kamala within the 'well educated' bracket in the village.

${ }_{35} 550$ Saudi riyals, or about US\$ 220 .

${ }_{36}$ In Sri Lanka custom dictates that a family member must supervise all hired workers to ensure diligence and prevent theft.

37 For more on this topic, see G. Gamburd (1972: $308 \mathrm{ff}$.)

${ }_{38}$ sata pahakvat naeae. In his story, Premasiri presents himself as the major maker of decisions. Since I did not speak with his wife, I do not know how great a role she might have played.

${ }_{39}$ At a 1978 exchange rate, I estimate Lalita's salary at about $\$ 200$ a month, or double what most maids made in 1994. Agency fees of Rs. 675/ or $\$ 40$ then now compare at fees of Rs. $13,500 /$ or $\$ 270$, nearly seven times as great.

${ }_{40}$ At a 1981 exchange rate, I estimate her salary at about $\$ 125$ a month. Her savings amount to about $\$ 3150$.

${ }_{41}$ The land cost $12,000 /$ (US $\$ 400$ at 1989 exchange rates) and they spent $25,000 /$ (US\$ 830 at 1989 exchange rates) on house repairs.

${ }_{42}$ During the same time period, many men indulged in gambling, drinking, and fighting.

${ }_{43}$ Sinhalese families eat in ranked stages, starting with the father, the male children, the female children, and ending with the mother. In poor families, adult women go hungry more often than other people. In some families adult men put children before them, but for Shriyani's father to have gone hungry when his daughter ate represented a large sacrifice in local terms. Dr. Malsiri Dias writes, "Within a poor household with decreasing food supplies, the wife/ mother would have had no alternative except to cut back on the dietary intake of the family or seek means of supplementing the family resources. Culturally, it was not only her responsibility to cook the 
meals but also to serve them. As the last person to eat, depleted food stocks would have lead to certain sacrifices on her part"(1991: 40).

44 Arrack, legally distilled from coconut palm sap, cost Rs. 120/ (US\$ 2.50)

per bottle; eight bottles would come to about Rs. 1000/ (US\$20). 